\title{
Spatio-Temporal Prediction of Dialectal Variant Usage
}

\author{
Péter Jeszenszky \\ Department of Geography, \\ Ritsumeikan University \\ 58, Komatsubara Kitamachi, Kita-ku \\ 603-8341 Kyoto \\ pjeszenszky@gmail . com
}

Philipp Stöckle

Austrian Centre for Digital Humanities, Austrian Academy of Science

Postgasse 7-9

1010 Vienna

philipp.stoeckledoeaw.ac.at

\author{
Panote Siriaraya \\ Kyoto Institute of Technology \\ Matsugasaki, Sakyo-ku \\ 606-8585 Kyoto \\ spanotedgmail.com
}

\author{
Adam Jatowt \\ Department of Social Informatics, \\ Kyoto University \\ Yoshida-Honmachi, Sakyo-ku \\ 606-8501 Kyoto \\ adamedl.kuis.kyoto-u.ac.jp
}

\begin{abstract}
The distribution of most dialectal variants have not only spatial but also temporal patterns. Based on the 'apparent time hypothesis', much of dialect change is happening through younger speakers accepting innovations $^{1}$. Thus, synchronic diversity can be interpreted diachronically. With the assumption of the 'contact effect', i.e. contact possibility (contact and isolation) between speaker communities being responsible for language change, and the apparent time hypothesis, we aim to predict the usage of dialectal variants. In this paper we model the contact possibility based on two of the most important factors in sociolinguistics to be affecting language change: age and distance. The first steps of the approach involve modeling contact possibility using a logistic predictor, taking the age of respondents into account. We test the global, and the local role of age for variation where the local level means spatial subsets around each survey site, chosen based on $k$ nearest neighbors. The prediction approach is tested on Swiss German syntactic survey data, featuring multiple respondents from different age cohorts at survey sites. The results show the relative success of the logistic prediction approach and the limitations of the method, therefore further proposals are made to develop the methodology.
\end{abstract}

\section{Motivation}

Contact and isolation, in geographic space and in social space, are assumed to be the most impor-

\footnotetext{
${ }^{1}$ An innovation is, of course, relative. A locally appearing new form with or without attestation elsewhere can be considered an innovation.
}

tant factors behind language change. The concept of apparent time (Bailey et al., 1991) hypothesizes that mother tongue is mostly acquired until the late teenage, after which one's language is more resistant to change. Throughout an individual's life contact patterns and social network might change (e.g., due to the ease of contact through media and changing migration or commuting patterns - especially from the $20^{\text {th }}$ century). However, based on the apparent time hypothesis, if not uprooted, an individual's linguistic patterns can be assumed to reflect the contact patterns of their early life. With keeping all other variables constant, it can be assumed that for two people that are close in age and spent their youth near each other, the chance for a similar language is higher.

Thus, the quantification of contact possibility allows predicting current language usage and, through the concept of 'apparent time depth', future dialect change. If it is possible to predict the usage of variants based on the contact among users, core issues in sociolinguistics and diachronic linguistics such as the diffusion of variants, tracing back and forecasting change in language can be addressed with a better (spatial and temporal) granularity. Besides, through such an approach, linguistic theories long used, such as the apparent time concept (Bailey et al., 1991), language change following gravity-like paths (Trudgill, 1974) or wave-like diffusion (Yokoyama and Sanada, 2009; Blythe and Croft, 2012), can be tested. Further, it can contribute to natural language processing endeavours, such as predicting age from language attributes (Morgan-Lopez et al., 2017). 
This study, tracing language variation back to the patterns of contact between communities, contributes to existing approaches (e.g., Pickl and Rumpf, 2012; Wieling and Nerbonne, 2015; Yamauchi and Murawaki, 2016; Burridge, 2017) in language change and variation studies. So far linguistic geography mostly tested individual phenomena (Willis, 2017), but as obtaining data with better granularity becomes increasingly faster, computational approaches can speed up analysis in language change studies, and highlight variants that can be then more thoroughly investigated with the methods of qualitative and quantitative linguistics.

To account for the diverse roles of contact quantitatively, the relationship of the measured linguistic variation and variables affecting contact patterns - including social, demographic, policyrelated or geographic factors - has to be tested. This paper is not the first step in this direction, with sociolinguistics and linguistic geography extensively having researched social status, geographic distances and trade, among others, in these regards (e.g., Labov, 1963; Gooskens, 2004; Nerbonne, 2009; Szmrecsanyi, 2012; Lameli et al., 2015). However, this paper shows one of the first steps towards assembling a model for predicting usage of dialectal variants, and thereby, language change by means of taking as many extralinguistic variables as possible into account. In this paper we start assembling the model by taking two main variable assumed by sociolinguistics to have a crucial impact on language contact and change: age and distance. In a previous paper (Jeszenszky et al., 2018), we provided first steps from the ordination aspect for assessing the spatial predictors of different grammatical domains.

The specific goal of this paper is to analyze the roles that age and distance play in language contact, as explanatory variables for the usage patterns of dialectal variants, tested at the linguistic level of syntax. We build a logistic predictor model at global and local scales for classifying multivariate syntactic data from a Swiss German dialect survey and present first results.

\section{Materials and Methods}

\subsection{Dialect Data}

It is often assumed in dialectology that of all linguistic levels, change in syntax is the slowest (Longobardi and Guardiano, 2009). It could mean that the association with age might be lower in syntax than for lexicon (Morgan-Lopez et al., 2017). However, the lower possible number of syntactic variants allows for more robust results with fewer responses in a survey.

The dialectal data used in this paper stems from the database of the Syntactic Atlas of German-speaking Switzerland (SADS; (Bucheli and Glaser, 2002; Glaser and Bart, 2015)). The database holds data collected in a series of four dialect surveys, which was conducted between 2000 and 2002, and probed 54 different (morpho)syntactic phenomena. At 383 survey sites, relatively homogeneously distributed throughout the German-speaking area, a total of 3'174 respondents (multiple respondents, 3-26 per survey site, median=7) filled in the questionnaires containing 118 questions. Respondents of several age groups (12-94 years old) were included at most survey sites. However, the age distribution is slightly skewed, with a median of 57 years (Stoeckle, 2018). The multitude of responses shows the local variation in variant usage, and give a higher attribute granularity and thus allows testing the association of variant usage and extralinguistic variables, such as age. Most survey questions involved translation from Standard German to the local dialect and multiple choice (MC) questions. For MC questions however, respondents could accept several answer variants as locally valid, and they were asked to specify their 'preferred' variants. In this work we rely on these preferred variants, as especially younger respondents tended to accept more variants (Glaser et al., 2019) - a clue for age as a factor conditioning usage patterns of dialectal variants. It has to be noted that even though dialectological research often refers to survey questions as variables, in this paper we call them 'phenomena', as the term 'variable' overlaps with the statistical terms used further on (i.e., explanatory variable, independent variable).

\subsection{Predicting Dialectal Variant Usage Based on Age and Spatial Neighborhood}

This paper presents the methodology and first results of our proposed approach for analysing the effects of age and regional contact. Regional contact is assumed to be more important in language change, manifesting itself in the variation of dialectal variants by age. We test the following two hypotheses: 
- At the global scale, age explains the usage of dialect variants in linguistic phenomena.

- Age is a better predictor for the usage of dialect variants at the local scale.

Firstly, using logistic regression, similarly to Willis (2017), we analyse the predictive power of age at the global level, taking into account all respondents, for the usage of variants that correspond to dialectal phenomena. Secondly, we utilize a regionalisation approach: for every survey site $s$, taking a set of $k$ nearest survey sites, we predict the usage of each variant in $s$, based on the age of respondents and the variant preference in the whole set.

Global scale. We test the association between linguistic variation as a categorical (nominal) variable and age as a continuous predictor variable, using logistic regressions. Logistic regression does not provide a good effect size statistic similar to $R^{2}$ used for Pearson's product-moment correlation. Nevertheless, its predictive power can be tested by training the logistic regression predictor on a training set in the data and checking whether the predictions of this model correspond to the observed data previously masked. We use a 10 -fold cross-validation strategy, with all data used in the training set and all observed data predicted. This tests whether logistic regression based on age provides a significant prediction on the usage of variants at the global level, and if so, with what accuracy. Thus, we report in Figure 1 the significance in a binary way (i.e., whether the prediction of the usage of a certain variant is significant or not). Besides, we present the $A U C$ in Figure 1 as well, as a typical performance measurement for binary classifiers, showing the separability, i.e., to what degree the model is capable of distinguishing between classes. The higher the $A U C$, better the model is at predicting $0 \mathrm{~s}$ as $0 \mathrm{~s}$ and $1 \mathrm{~s}$ as $1 \mathrm{~s}$.

Local scale. The regional approach can be viewed as a classification problem. Our model has to decide for each variant whether respondents at a central survey site $s$ used it or not, based on age as the predictor variable in a set of $k$ nearest neighbor survey sites. We use a logistic regression approach again. Using age as continuous and answer variants of all respondents as boolean variables, we train a logistic model and predict the variant usage for each respondent at $s$. We do this for all 383 survey sites. In this paper, we choose the $k$ nearest neighbors based on Euclidean distance and we test models with different $k$ values (5 to 50). Our approach employs distance cut-off, rather than distance decay, however it can also be assumed that the closer survey sites are, the more linguistic influence they have on each other.

\section{Results}

For this paper, we used 60 phenomena from the SADS survey (approximately half of all), which were already used in Jeszenszky et al. (2017). Appendix A provides some linguistic details on each phenomenon.

Results with regards to the explanatory value of age as a global predictor for variant usage are presented in Figure 1. For more than half of the variants considered, age is not a significant predictor (dark grey squares). The $A U C$ values of separability, reported for the variants where the relationship with age is significant, are relatively low $(0.5$ means no discriminative capacity of the model). At the same time, variants that reach higher values typically have relatively few users (below 100 out of 3'714), e.g., II5 $3^{2}$; 10 users and II30_7; 8 users. However, several variants with sparse usage are also found among those not predicted significantly by age. Variants with many users (e.g., I12_1; 2'683 users, I7_3; 2'880 users, $I I I 2 \_1 ; 2$ '021 users) typically have an $A U C$ value between 0.5 and 0.6. These values of association between variant usage and age alone are relatively low overall, leading us to investigate the prediction power of age at the regional scale, the patterns of which are possibly concealed by the global patterns.

For each variant in each phenomenon, Figure 2 presents the number of survey sites (out of the total 383) in which age significantly predicts the variant's usage, based on $k=13$ nearest neighbors. It is visible that age proves to be a significant predictor in a large amount or survey sites only for a few variants. These are, however, not always variants with a few users. The first few variants in each phenomenon usually cover the majority of respondents.

The distribution of one such variant (III/_2) is mapped in Figure 3 along with the significance and accuracy of the predictor variable age. The patterns in Figure 3 show that the higher number

\footnotetext{
${ }^{2}$ Variant coding includes the survey question number and a variant ID. For example, II5_3 is Variant \#3 in the $5^{\text {th }}$ question of the $2^{\text {nd }}$ survey sheet
} 


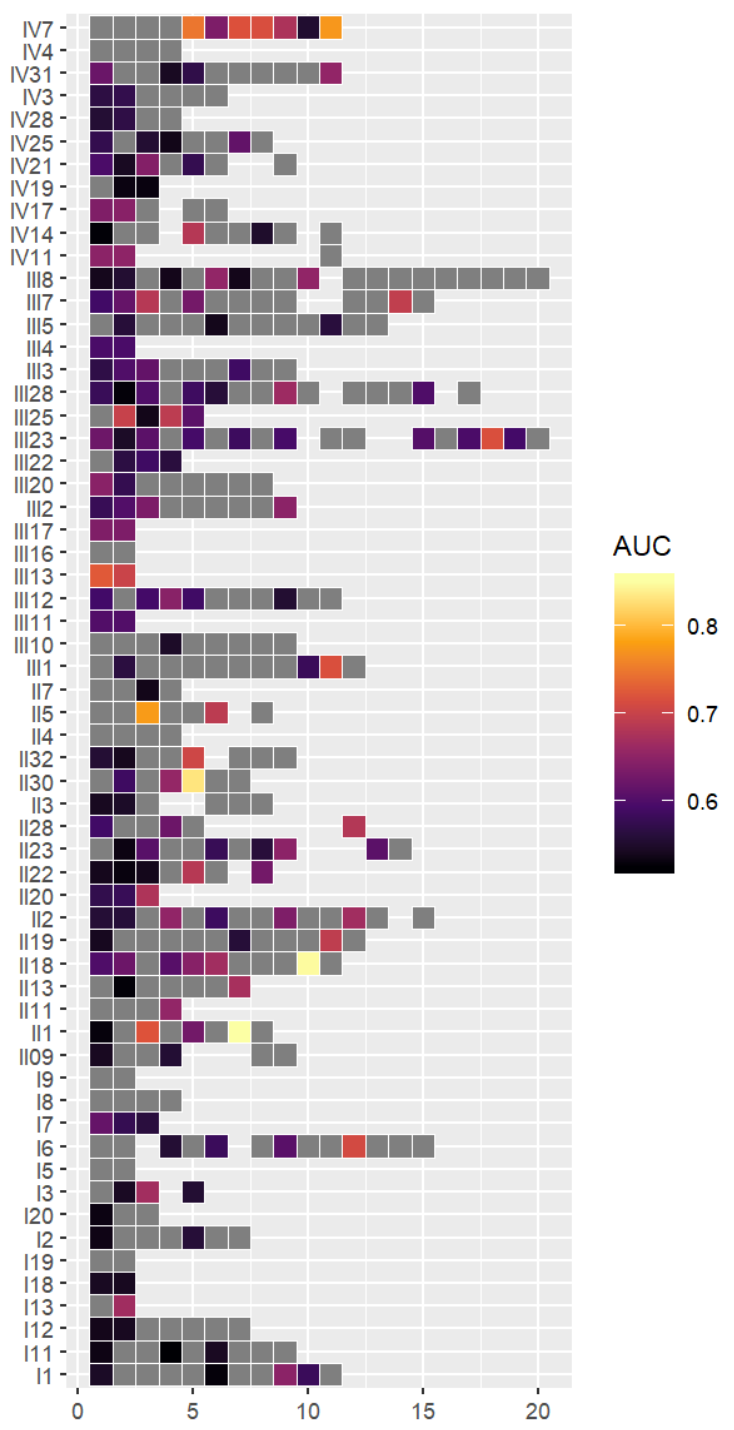

Figure 1: The global prediction power of logistic regression. The $A U C$ values are plotted for each variant (horizontal axis) corresponding to the 60 linguistic phenomenon (vertical axis). Non-significance of the logistic regression is shown by dark grey squares.

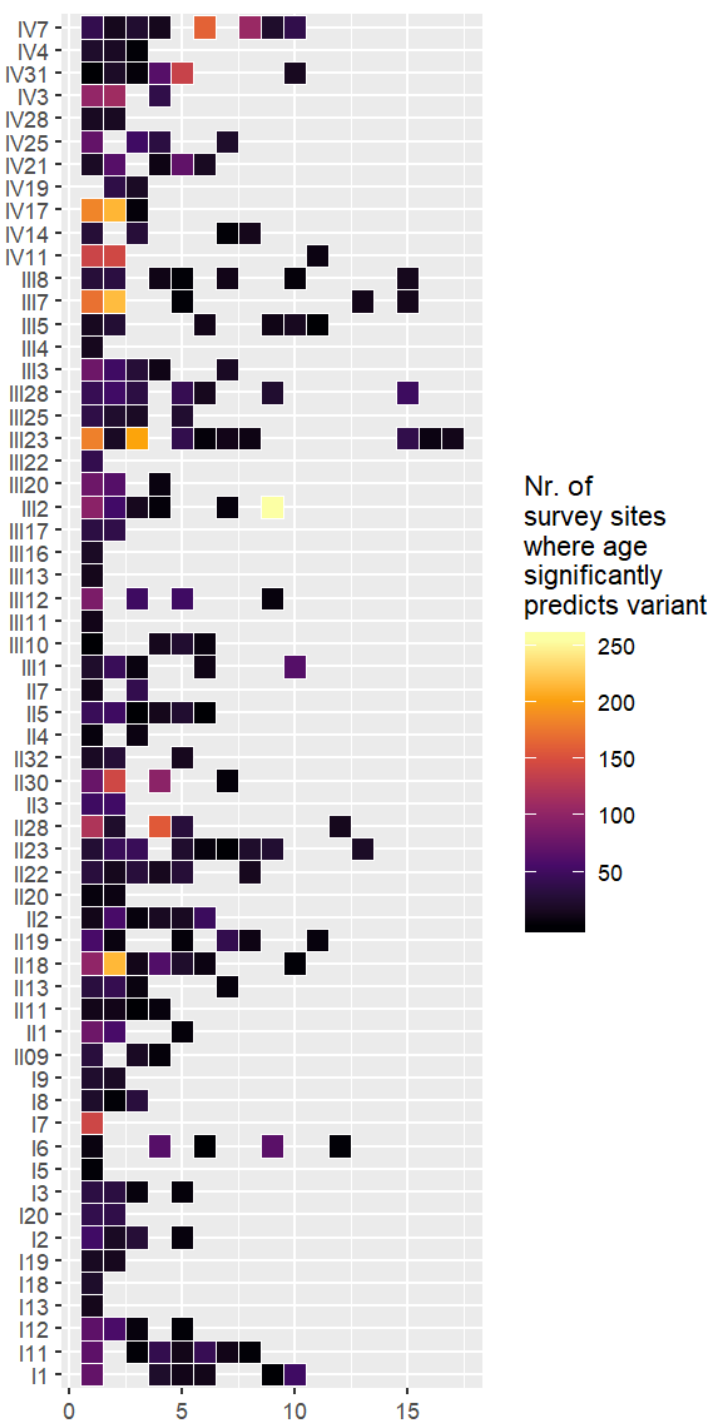

Figure 2: The local prediction power of logistic regression. For each phenomenon and variant, the colour corresponds to the number of survey sites for which the logistic regression on age proved significant, based on $k=13$ nearest neighbors. 


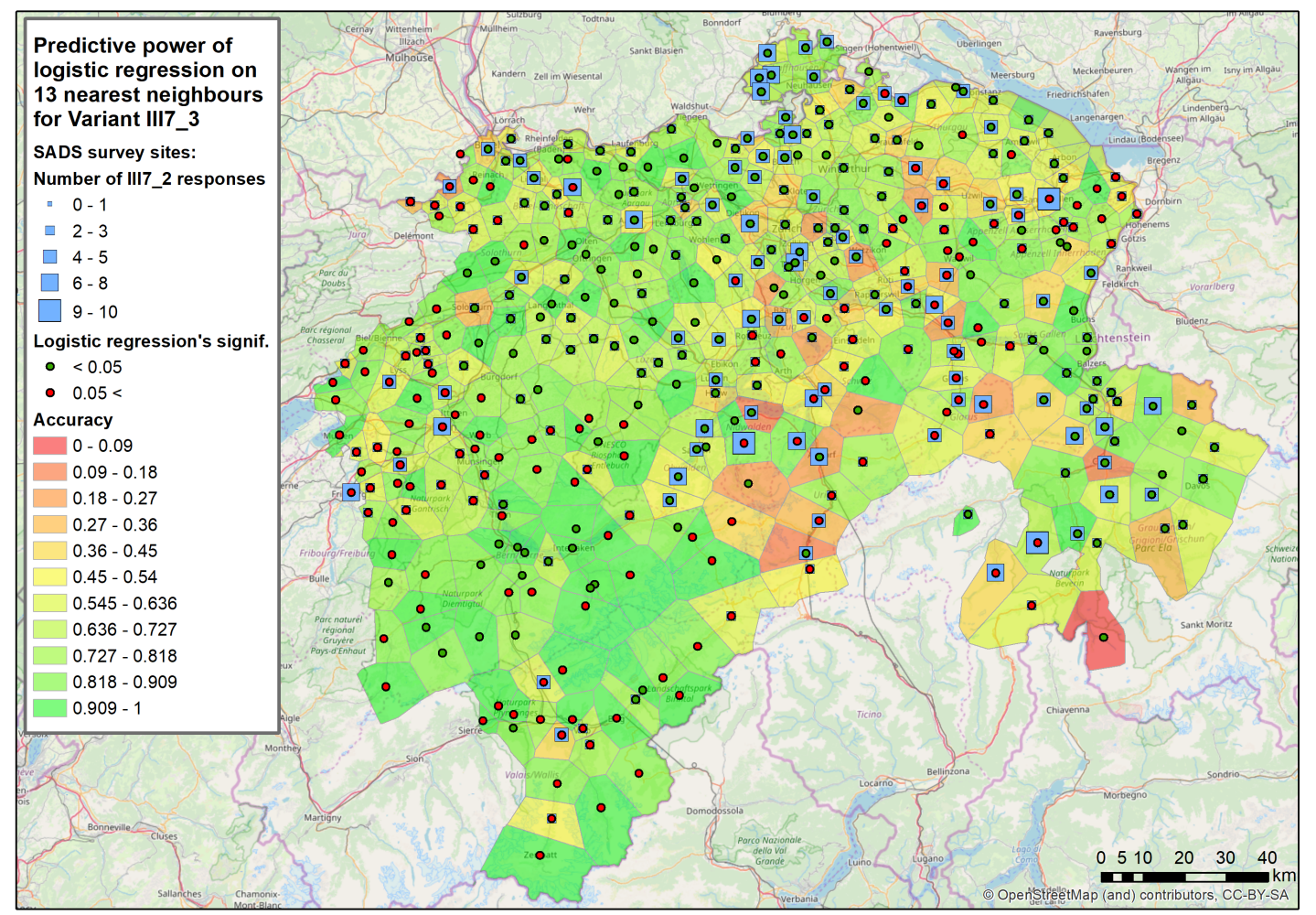

Figure 3: Mapping the significance $(p<0.05)$ and the accuracy of the logistic regression, for an answer variant 'hät s mer erzählt' of Phenomenon III7, investigating the 'position of the personal pronouns', based on age and $k=13$ nearest neighbors. Blue squares show the number of respondents using this variant. Accuracy is calculated by the proportion of correctly predicted usage.

of users does not necessarily make age a significant predictor. Significance of age as a predictor variable is spatially autocorrelated, which can be interpreted as follows. When present, the usage of this variant is characteristic of certain age groups at survey sites with green points, while at red ones it is used by different age groups.

As logistic regression is sensitive to class imbalances, it might not always be the best choice as a predictor when there are a lot of 0 s and only a few $1 \mathrm{~s}$ in the data, as it might result in false accuracy by predicting 0 s only and not the $1 \mathrm{~s}$.

Interpretations of the first results show that age alone does not prove to be an exceptionally good predictor of syntactic variation. This is partly due to the nature of the data. It has been shown that while lexicon is more prone to have a correlation with age, syntax changes slower. The first results, however, show that already with a relatively simple approach, our research direction seems to be a worthwhile undertaking. Therefore, we have a wide outlook for further developing the methodology. The area and number of respondents involved in each model will be tested through different values of $k$, a distance decay approach and weights based on different parameters (including age). The spatial basis of the model will feature estimations of contact potential that have proved more 'informative' than Euclidean distance, such as travel time (Jeszenszky et al., 2017); linguistic gravity (Trudgill, 1974), predicting influence and therefore language change based on settlement populations as weights in a gravity equation; or linguistic distance (Pickl et al., 2014), assuming that the closer dialect varieties should be the outcomes of closer (historical) contact. Furthermore, different algorithms beyond the logistic predictor (e.g., random forests, SVM, XGBoost) will be tested in the prediction model.

\section{Acknowledgments}

We are grateful to Elvira Glaser, Gabi Bart and Sandro Bachmann of the Syntactic Atlas of German-speaking Switzerland (SADS) project for the provision and professional help with the linguistic data. Funding by the Swiss National Science Foundation (Project no. P2ZHP2_175019) is gratefully acknowledged. Further, we would like to acknowledge the comments of the anonymous reviewers. 


\section{References}

Guy Bailey, Tom Wilke, Jan Tillery, and Lori Sand. 1991. The apparent time construct. Language Variation and Change, 3(1991):241-264.

Richard A. Blythe and William A. Croft. 2012. Scurves and the mechanisms of propagation in language change. Language, 88(Number 2):269-304.

Claudia Bucheli and Elvira Glaser. 2002. The Syntactic Atlas of Swiss German dialects: Empirical and methodological problems. In Sjef Barbiers, Leonie Cornips, and Susanne van der Kleij, editors, Syntactic Microvariation, vol. 2. edition, pages 41-73. Meertens Institute Electronic Publications in Linguistics, Amsterdam.

James Burridge. 2017. Spatial evolution of human dialects. Physical Review X, 7(031008).

Elvira Glaser and Gabriela Bart. 2015. Dialektsyntax des Schweizerdeutschen. In Roland Kehrein, Alfred Lameli, and Stefan Rabanus, editors, Regionale Variation des Deutschen. Projekte und Perspektiven., chapter 4, pages 79-105. De Gruyter, Berlin.

Elvira Glaser, Philipp Stoeckle, and Sandro Bachmann. 2019. Faktoren und Arten intrapersoneller Variation im Material des syntaktischen Atlas der deutschen Schweiz (SADS). In Syntax aus Saarbrücker Sicht 3.: Beiträge der SaRDiS-Tagung zur Dialektsyntax 2018, pages 1-30, Stuttgart. Steiner.

Charlotte Gooskens. 2004. Norwegian dialect distances geographically explained. In Language Variation in Europe. Papers from the Second International Conference on Language Variation in Europe ICLAVE Vol. 2. 2004., pages 195-206, Uppsala.

Péter Jeszenszky, Sandro Bachmann, and Peter Ranacher. 2018. Towards the parameterisation and quantification of dialect contact potential: An extended abstract. In GIScience 2018 unpublished extended abstract, pages 1-6.

Péter Jeszenszky, Philipp Stoeckle, Elvira Glaser, and Robert Weibel. 2017. Exploring global and local patterns in the correlation of geographic distances and morphosyntactic variation in Swiss German. Journal of Linguistic Geography, 5(2):86-108.

William Labov. 1963. The Social Motivation of a Sound Change. $i i_{i} W O R D ; / i_{i}, 19(3): 273-309$.

Alfred Lameli, Volker Nitsch, Jens Südekum, and Nikolaus Wolf. 2015. Same same but different: Dialects and trade. German Economic Review, 16(3):290-306.

Giuseppe Longobardi and Cristina Guardiano. 2009. Evidence for syntax as a signal of historical relatedness. Lingua, 119(11):1679-1706.
Antonio A. Morgan-Lopez, Annice E. Kim, Robert F. Chew, and Paul Ruddle. 2017. Predicting age groups of Twitter users based on language and metadata features. PLoS ONE, 12(8):1-12.

John Nerbonne. 2009. Data-Driven Dialectology. Language and Linguistics Compass, 3(1):175-198.

Simon Pickl and Jonas Rumpf. 2012. Dialectometric concepts of space: Towards a variant-based dialectometry. In Sandra Hansen, Christian Schwarz, Philipp Stoeckle, and Tobias Streck, editors, Dialectological and Folk Dialectological Concepts of Space - Current Methods and Perspectives in Sociolinguistic Research on Dialect Change, linguae \& edition, pages 199-214. Walter de Gruyter, Berlin/ New York.

Simon Pickl, Aaron Spettl, Simon Magnus Pröll, Stephan Elspaß, Werner König, and Volker Schmidt. 2014. Linguistic distances in dialectometric intensity estimation. Journal of Linguistic Geography, 2(01):25-40.

Philipp Stoeckle. 2018. Zur Syntax von afa (anfangen') im Schweizerdeutschen - Kookkurrenzen, Variation und Wandel. In Syntax aus Saarbrücker Sicht 2. Beiträge der SaRDiS-Tagung zur Dialektsyntax, pages 173-203, Stuttgart. Steiner.

Benedikt Szmrecsanyi. 2012. Geography is overrated. In Sandra Hansen, Christian Schwarz, Philipp Stoeckle, and Tobias Streck, editors, Dialectological and Folk Dialectological Concepts of Space Current Methods and Perspectives in Sociolinguistic Research on Dialect Change, pages 215-231. De Gruyter, Berlin, Boston.

Peter Trudgill. 1974. Linguistic change and diffusion: Description and explanation in sociolinguistic dialect geography. Language in Society, 2:215-246.

Martijn Wieling and John Nerbonne. 2015. Advances in Dialectometry. Annual Review of Linguistics, $1(1): 243-264$.

David Willis. 2017. Investigating geospatial models of the diffusion of morphosyntactic innovations: The Welsh strong second-person singular pronoun chdi. Journal of Linguistic Geography, 5:41-66.

Kenji Yamauchi and Yugo Murawaki. 2016. Contrasting Vertical and Horizontal Transmission of Typological Features. Proceedings of the 26th International Conference on Computational Linguistics (COLING-16), pages 836-846.

Shoichi Yokoyama and Haruko Sanada. 2009. Logistic regression model for predicting language change. In Reinhard Köhler, editor, Studies in Quantitative Linguistics 5, Issues in Quantitative Linguistics, pages 176-192. RAM-Verlag, Lüdenscheid (D). 


\section{A Appendices}

A Appendix contains the 60 dialectal variables from the SADS in Table 1, 2 and 3, based on which the analysis was carried out. 


\begin{tabular}{|c|c|c|c|}
\hline $\begin{array}{l}\text { SADS } \\
\text { ID }\end{array}$ & Sentence (Standard German) & Sentence in English & Linguistic phenomenon \\
\hline I.1 & $\begin{array}{l}\text { Entschuldigung, ich habe zu } \\
\text { wenig Kleingeld, um ein Bil- } \\
\text { lett } z u \text { lösen. }\end{array}$ & $\begin{array}{l}\text { Excuse me, I don't have } \\
\text { enough change in order to buy } \\
\text { a ticket. }\end{array}$ & $\begin{array}{l}\text { infinitival purposive } \\
\text { clause: linkage }\end{array}$ \\
\hline $\mathbf{I . 2}$ & $\begin{array}{l}\text { Wem will er denn die schönen } \\
\text { Blumen bringen? }\end{array}$ & $\begin{array}{l}\text { To whom does he want to bring } \\
\text { those beautiful flowers? }\end{array}$ & $\begin{array}{ll}\text { prepositional } & \text { dative } \\
\text { marking (PDM) } & \\
\end{array}$ \\
\hline I.3 & $\begin{array}{l}\text { Oh, ich habe den Fritz kommen } \\
\text { hören. }\end{array}$ & Oh, I heard Fritz coming. & $\begin{array}{l}\text { perfect with 'hear': form } \\
\text { and position of non-finite } \\
\text { verb (IPP) }\end{array}$ \\
\hline I.5 & Der Korb ist umgekippt. & The basket is toppled over. & $\begin{array}{l}\text { resultative: subject agree- } \\
\text { ment }\end{array}$ \\
\hline$\overline{I .6}$ & $\begin{array}{l}\text { Wissen Sie, jetzt brauche } \\
\text { ich sogar Tabletten zum } \\
\text { einschlafen. }\end{array}$ & $\begin{array}{l}\text { You know, now I even need } \\
\text { pills in order to fall asleep. }\end{array}$ & $\begin{array}{l}\text { infinitival purposive } \\
\text { clause: linkage }\end{array}$ \\
\hline I.7 & $\begin{array}{l}\text { Nein, das gehört meiner } \\
\text { Schwester. }\end{array}$ & No, it belongs to my sister. & $\begin{array}{ll}\text { prepositional } & \text { dative } \\
\text { marking (PDM) } & \\
\end{array}$ \\
\hline $\mathbf{I . 8}$ & $\begin{array}{l}\text { Aber ich habe im Fall schon } \\
\text { gestern geholfen abzuwaschen. }\end{array}$ & $\begin{array}{l}\text { But I already helped doing the } \\
\text { dishes yesterday. }\end{array}$ & $\begin{array}{l}\text { perfect with 'help': form } \\
\text { and position of non-finite } \\
\text { verb (IPP) }\end{array}$ \\
\hline I.9 & $\begin{array}{l}\text { Also ich weiss auch nicht, ob } \\
\text { er einmal heiraten will. }\end{array}$ & $\begin{array}{l}\text { Well, I don't know if he ever } \\
\text { wants to get married. }\end{array}$ & $\begin{array}{l}\text { modal verb in subordinate } \\
\text { clauses: position }\end{array}$ \\
\hline I.11 & $\begin{array}{l}\text { Aber jetzt habe ich mich ger- } \\
\text { ade hingesetzt, } u m \text { ein Buch } z u \\
\text { lesen. }\end{array}$ & $\begin{array}{l}\text { But I just sat down in order to } \\
\text { read a book. }\end{array}$ & $\begin{array}{l}\text { infinitival purposive } \\
\text { clause: linkage }\end{array}$ \\
\hline $\mathbf{I . 1 2}$ & $\begin{array}{l}\text { Fischstäbchen muss man doch } \\
\text { gefroren anbraten. }\end{array}$ & $\begin{array}{l}\text { Actually, fish fingers should be } \\
\text { fried while still frozen. }\end{array}$ & copredicative participle \\
\hline $\mathbf{I . 1 3}$ & Da wird gearbeitet. & $\begin{array}{l}\text { lit. Here will be worked. (Peo- } \\
\text { ple are working here.) }\end{array}$ & $\begin{array}{l}\text { expletive 'it' (impersonal } \\
\text { passive) }\end{array}$ \\
\hline I.18 & Soll ich welche kaufen? & Should I buy some of that? & partitive object (pronoun) \\
\hline I.19 & $\begin{array}{l}\text { Ich habe keine Ahnung, ob sie } \\
\text { das Auto schon bezahlt hat. }\end{array}$ & $\begin{array}{l}\text { I have no idea whether she has } \\
\text { already paid for the car. }\end{array}$ & $\begin{array}{l}\text { perfect auxiliary ('have') } \\
\text { in subordinate clauses: } \\
\text { position }\end{array}$ \\
\hline I.20 & $\begin{array}{l}\text { Aber ich habe doch das Buch } \\
\text { dir geschenkt. }\end{array}$ & $\begin{array}{l}\text { But I gave the book as a } \\
\text { present to you. }\end{array}$ & $\begin{array}{ll}\text { prepositional } & \text { dative } \\
\text { marking (PDM) } & \\
\end{array}$ \\
\hline II.1 & Hast du die Uhr flicken lassen? & Have you had the clock fixed? & $\begin{array}{l}\text { infinitive particle (dou- } \\
\text { bling/position) 'let' }\end{array}$ \\
\hline II.2 & $\begin{array}{l}\text { Das ist doch die Frau, der ich } \\
\text { schon lange das Buch bringen } \\
\text { sollte. }\end{array}$ & $\begin{array}{l}\text { This is the woman to whom I } \\
\text { should have brought back the } \\
\text { book long ago. }\end{array}$ & $\begin{array}{l}\text { relative clause linkage: } \\
\text { IO }\end{array}$ \\
\hline II.3 & $\begin{array}{l}\text { Er lässt den Schreiner kom- } \\
\text { men. }\end{array}$ & $\begin{array}{l}\text { lit. He lets the carpenter come. } \\
\text { (He calls the carpenter.) }\end{array}$ & $\begin{array}{l}\text { infinitive particle (dou- } \\
\text { bling/position) 'let' }\end{array}$ \\
\hline II.4 & Du hast sicher viel zu erzählen! & You must have a lot to tell! & $\begin{array}{l}\text { non-finite form with 'have } \\
\text { to' (gerund) }\end{array}$ \\
\hline II.5 & Ihr dürft alles liegen lassen. & $\begin{array}{l}\text { lit. You can let everything lie. } \\
\text { (You can leave everything.) }\end{array}$ & $\begin{array}{l}\text { infinitive particle (dou- } \\
\text { bling/position) 'let' }\end{array}$ \\
\hline II.7 & $\begin{array}{l}\text { Ich habe erst mit vierzig fahren } \\
\text { gelernt. }\end{array}$ & $\begin{array}{l}\text { I have only learnt to drive at } \\
\text { forty. }\end{array}$ & $\begin{array}{l}\text { perfect with 'learn': form } \\
\text { and position of non-finite } \\
\text { verb (IPP) }\end{array}$ \\
\hline
\end{tabular}

Table 1: The linguistic phenomena in SADS used in the experiments (part 1). The grammatical constructs of interest are highlighted in italics. 


\begin{tabular}{|c|c|c|c|}
\hline $\begin{array}{l}\text { SADS } \\
\text { ID }\end{array}$ & Sentence (Standard German) & Sentence in English & Linguistic phenomenon \\
\hline II.9 & $\begin{array}{l}\text { Nein, sie ist gerade verkauft } \\
\text { worden. }\end{array}$ & No, it has just been sold. & $\begin{array}{l}\text { passive auxiliary and } \\
\text { agreement }\end{array}$ \\
\hline II.11 & $\begin{array}{l}\text { Er hat die Hand immer noch } \\
\text { eingebunden. }\end{array}$ & He has his arm still bandaged. & $\begin{array}{l}\text { resultative: object agree- } \\
\text { ment }\end{array}$ \\
\hline II.13 & $\begin{array}{l}\text { Du musst die Milch aber heiss } \\
\text { trinken! }\end{array}$ & $\begin{array}{l}\text { But you have to drink the milk } \\
\text { hot! }\end{array}$ & copredicative adjective \\
\hline II.18 & $\begin{array}{l}\text { Das ist der Mann, dem ich } \\
\text { gestern den Weg gezeigt habe. }\end{array}$ & $\begin{array}{l}\text { That's the man to whom I gave } \\
\text { directions yesterday. }\end{array}$ & $\begin{array}{l}\text { relative clause linkage: } \\
\text { IO }\end{array}$ \\
\hline II.19 & $\begin{array}{l}\text { Und dann ist ein Fuchs } \\
\text { geschlichen gekommen! }\end{array}$ & $\begin{array}{l}\text { And then a fox came creeping } \\
\text { around! }\end{array}$ & $\begin{array}{l}\text { verbal construction } \\
\text { 'come' }+ \text { motion verb }\end{array}$ \\
\hline II.20 & $\begin{array}{l}\text { Ich möchte aber ein Auto, das } \\
\text { ich auch bezahlen kann! }\end{array}$ & $\begin{array}{l}\text { But I want a car that I can ac- } \\
\text { tually pay for! }\end{array}$ & $\begin{array}{l}\text { relative clause linkage: } \\
\text { DO }\end{array}$ \\
\hline II.22 & Nein, das ist Peters [Dreirad]. & No, that's Peter's. [tricycle] & predicative possessive \\
\hline II.23 & $\begin{array}{l}\text { Nein, das ist Sandras } \\
\text { [Dreirad]. }\end{array}$ & No, that's Sandra's. [tricycle] & predicative possessive \\
\hline II.28 & $\begin{array}{l}\text { Das ist der Mann, mit dem ich } \\
\text { immer schwätze. }\end{array}$ & $\begin{array}{l}\text { That's the man that I always } \\
\text { chat with. }\end{array}$ & $\begin{array}{l}\text { relative clause linkage: } \\
\text { PP }\end{array}$ \\
\hline II.30 & Der Hund des Lehrers & The teacher's dog & adnominal possessive \\
\hline II.32 & Ich habe Fritz gesehen & I have seen Fritz. & $\begin{array}{l}\text { personal name: definite } \\
\text { article and case inflection }\end{array}$ \\
\hline III.1 & $\begin{array}{l}\text { Wenn es so warm bleibt, fängt } \\
\text { das Eis an zu schmelzen! }\end{array}$ & $\begin{array}{l}\text { If it stays this warm, the ice } \\
\text { will begin to melt. }\end{array}$ & $\begin{array}{l}\text { infinitive particle (posi- } \\
\text { tion/doubling) 'begin' }\end{array}$ \\
\hline III.2 & Wen suchst du? & Who are you looking for? & $\begin{array}{l}\text { interrogative pronoun: } \\
\text { case }\end{array}$ \\
\hline III.3 & $\begin{array}{l}\text { Für wen sind denn die Blu- } \\
\text { men? }\end{array}$ & Who are the flowers for? & $\begin{array}{l}\text { interrogative pronoun: } \\
\text { case }\end{array}$ \\
\hline III.4 & Die sind nicht für dich! & They are not for you! & $\begin{array}{l}\text { personal pronoun }(2 \mathrm{sg}) \text { : } \\
\text { PP }\end{array}$ \\
\hline III.5 & $\begin{array}{l}\text { Ich habe schon angefangen zu } \\
\text { kochen. }\end{array}$ & $\begin{array}{l}\text { I have already started cooking. } \\
\text { (lit. have begun to cook) }\end{array}$ & $\begin{array}{l}\text { infinitive particle (posi- } \\
\text { tion/doubling) 'begin' }\end{array}$ \\
\hline III.7 & Sie hat es mir gestern erzählt. & $\begin{array}{l}\text { She told that to me yesterday } \\
\text { [about expecting a baby]. }\end{array}$ & $\begin{array}{l}\text { personal pronouns: posi- } \\
\text { tion }\end{array}$ \\
\hline III.8 & $\begin{array}{l}\text { Sie findet es nicht gut, dass ich } \\
\text { angefangen habe zu rauchen. }\end{array}$ & $\begin{array}{l}\text { She doesn't find it good that } \\
\text { I have started smoking. (lit. } \\
\text { have begun to smoke) }\end{array}$ & $\begin{array}{l}\text { infinitive particle (posi- } \\
\text { tion/doubling) 'begin' }\end{array}$ \\
\hline III.10 & $\begin{array}{l}\text { Wenn sie dich erwischen, } \\
\text { bekommst du den Fahrausweis } \\
\text { entzogen! }\end{array}$ & $\begin{array}{l}\text { If they catch you, you get your } \\
\text { driver's license taken away. }\end{array}$ & 'get'-passive \\
\hline III.11 & Also mich erwischt keiner! & Well, no one will catch $m e !$ & $\begin{array}{l}\text { personal pronoun }(1 \mathrm{sg}) \text { : } \\
\text { DO }\end{array}$ \\
\hline
\end{tabular}

Table 2: The linguistic phenomena in SADS used in the experiments (part 2). 


\begin{tabular}{|c|c|c|c|}
\hline $\begin{array}{l}\text { SADS } \\
\text { ID }\end{array}$ & Sentence (Standard German) & Sentence in English & Linguistic phenomenon \\
\hline III.12 & $\begin{array}{l}\text { Nimm die Suppe sofort weg, } \\
\text { wenn sie zu kochen anfängt! }\end{array}$ & $\begin{array}{l}\text { Take the soup off immediately, } \\
\text { once it begins to boiling. }\end{array}$ & $\begin{array}{l}\text { infinitive particle (posi- } \\
\text { tion/doubling) 'begin' }\end{array}$ \\
\hline III.13 & $\begin{array}{l}\text { Er gibt sich einfach keine } \\
\text { Mühe. }\end{array}$ & $\begin{array}{l}\text { He just doesn't put any effort } \\
\text { into it. (lit. for himself) }\end{array}$ & reflexive pronoun (3sgm) \\
\hline III.16 & $\begin{array}{l}\text { Die Strasse ist schon seit einem } \\
\text { Jahr aufgerissen. }\end{array}$ & $\begin{array}{l}\text { The street has already been } \\
\text { torn up for a year. }\end{array}$ & $\begin{array}{l}\text { resultative: subject agree- } \\
\text { ment }\end{array}$ \\
\hline III.17 & Wir müssen $u n s$ das überlegen. & $\begin{array}{l}\text { We have to think about it. (lit. } \\
\text { for ourselves) }\end{array}$ & reflexive pronoun $(1 \mathrm{pl})$ \\
\hline III.20 & schaut nur für sich selbst. & He only thinks about himself. & pronoun (PP) \\
\hline III.22 & Sie ist grösser als ich. & She is taller than me. & $\begin{array}{l}\text { comparative clause link- } \\
\text { age }\end{array}$ \\
\hline III.23 & inkend ist er gelaufen. & ome limping. & converb \\
\hline III.25 & $\begin{array}{l}\text { Sie gehen halt lieber schwim- } \\
\text { men als laufen. }\end{array}$ & $\begin{array}{l}\text { They would rather go for a } \\
\text { swim than for a walk. }\end{array}$ & $\begin{array}{l}\text { comparative clause link- } \\
\text { age }\end{array}$ \\
\hline III.28 & $\begin{array}{l}\text { Dann ist er ja älter, als ich } \\
\text { gemeint habe. }\end{array}$ & So he is older than I expected. & $\begin{array}{l}\text { comparative clause link- } \\
\text { age }\end{array}$ \\
\hline IV.3 & $\begin{array}{l}\text { Ich habe es ihm schon } \\
\text { geschickt. }\end{array}$ & I have already sent it to him. & $\begin{array}{l}\text { personal pronouns: posi- } \\
\text { tion }\end{array}$ \\
\hline IV.4 & Wer ist das gewesen? & Who was it? & $\begin{array}{l}\text { interrogative pronoun: } \\
\text { case }\end{array}$ \\
\hline IV.7 & Jetzt kannst du anfangen. & Now you can begin. & $\begin{array}{l}\text { non-finite 'begin' with } \\
\text { modal verb }\end{array}$ \\
\hline IV.11 & $\begin{array}{l}\text { och, das ist im Fall er gewe- } \\
\text { n. }\end{array}$ & Yes, that must have been him! & $\begin{array}{l}\text { personal pronoun (3sgm): } \\
\text { subject }\end{array}$ \\
\hline IV.14 & $\begin{array}{l}\text { Du musst das Licht anzünden, } \\
\text { um zu lesen. }\end{array}$ & $\begin{array}{l}\text { You have to turn the light on in } \\
\text { order to read. }\end{array}$ & $\begin{array}{l}\text { infinitival purposive } \\
\text { clause: linkage }\end{array}$ \\
\hline IV.17 & $\begin{array}{l}\text { Doch, das ist } \text { er sicher gewe- } \\
\text { sen! }\end{array}$ & Yes, that was him for sure! & $\begin{array}{l}\text { personal pronoun (3sgm): } \\
\text { subject }\end{array}$ \\
\hline IV.19 & $\begin{array}{l}\text { Ja, ich habe etwas ganz } \\
\text { Schönes gekauft! }\end{array}$ & $\begin{array}{l}\text { Yes, I have bought something } \\
\text { really nice! }\end{array}$ & $\begin{array}{l}\text { indefinite pronoun: posi- } \\
\text { tion/doubling }\end{array}$ \\
\hline IV.21 & $\begin{array}{l}\text { Ich habe nicht gewusst, dass er } \\
\text { so spät fahren gelernt hat. }\end{array}$ & $\begin{array}{l}\text { I didn't know that he has learnt } \\
\text { to drive only so late. }\end{array}$ & $\begin{array}{l}\text { perfect with 'learn': form } \\
\text { and position of non-finite } \\
\text { verb (IPP) }\end{array}$ \\
\hline IV.25 & $\begin{array}{l}\text { Das glaubst du ja selber nicht, } \\
\text { dass sie so früh lesen gelernt } \\
\text { hat. }\end{array}$ & $\begin{array}{l}\text { No way she has learnt to read } \\
\text { so young! }\end{array}$ & $\begin{array}{l}\text { perfect with 'learn': form } \\
\text { and position of non-finite } \\
\text { verb (IPP) }\end{array}$ \\
\hline IV.28 & $\begin{array}{l}\text { Ich habe es (dem) Fritz } \\
\text { gegeben. }\end{array}$ & $\begin{array}{l}\text { I gave it to Fritz. (lit. to the } \\
\text { Fritz) }\end{array}$ & $\begin{array}{l}\text { personal name: definite } \\
\text { article and case inflection }\end{array}$ \\
\hline IV.31 & Das gefallen täte mir auch! & $\begin{array}{l}\text { approx. That would do to my } \\
\text { liking! (I would like it, too!) }\end{array}$ & $\begin{array}{l}\text { subjunctive auxiliary 'do' } \\
\text { (position) }\end{array}$ \\
\hline
\end{tabular}

Table 3: The linguistic phenomena in SADS used in the experiments (part 3). 